\title{
Complicated features and their solution in analysis of thin shell and plate structures
}

\author{
Govind Prasad Lamichhane
}

\author{
Mid-Western University \\ Post Box 21700, Kuhine Pani, Birendranagar, Surkhet, Nepal
}

(received: August 02, 2018; revised: October 08, 2018; accepted: November 10,2018)

\begin{abstract}
Introduction. It is instructive to assemble a list of applications from a historical point of view, and to take as a connecting theme the way in which the introduction of the thin shell as a structural form made an important contribution to the development of several branches of engineering. The following is a brief list, which is by no means complete and complicated features and their solutions for analysis of such structures.

Solution technique, methods. The linear theory of thin elastic shells with arbitrary shape of the middle surface is derived on the basis of Kirchhoff's assumptions that were used in the development of the plate bending theory introduced in Part I. These assumptions are formulated for the linear theory of thin shells of an arbitrary shape. The problem of the study of this article is to identify simple way of solution to analyze complicated features of thin shell structure by introducing modern and new programmable theories and aspects. Especially the intersecting line of connecting thin shell structures.

Results. It is possible to successfully model explicitly a panel profile that can be used for optimization studies for use as possible future test studies. It has also been shown, that if test data exists, a numerical solution can be very accurately modeled to match the test data by modifying the material properties of the model.

Discussion. The article should encourage structural engineers to solve complicated features in thin shell structures and design for construction of such structure which are rarely constructing in country like Nepal due to lack of skilled manpower.
\end{abstract}

Keywords: spatial structure, thin shells, surfaces, Monge surfaces, methods of analyses

\section{Introduction}

From the perspective of structural engineering, thin shells due to their spatial and complicated curvature, possess a structurally efficient way of carrying loads acting perpendicular to their surfaces. However, the nature and geometry of thin shells makes them complicated to understand or predict their structural behavior and analyze them [2-4].

It has been widely recognized by structural engineers and designers that shell structures are often the best option for the weight efficiency or the genuine use of materials. This is the reason why various types of shells keep being used despite their high-skilled workmanship demand. Real life shells such as largespan coverings of buildings, cooling towers, structural elements of nuclear power stations or offshore platforms are usually complex in geometry, complicated to analyze them and very expensive structures. The highest level of reliability that is required for these structures is heavily depended on the accuracy of measurements and the reliability and confidence of their structural analysis for structural engineers. The most popular and often the only tool available for this analysis is the finite element method [5-9] or global (super) element method [10-17]. But unfortunately, the results obtained using some FEM packages or software are not so reliable. The second way to test software for numerical analysis is to compare its results against a known analytical or programmed solution written with variation differential methods. But analytical solutions exist or cannot be obtained for complex geometrical structures. At the beginning of the FEM introduced, the finite difference method served as an alternative method for numerical analysis of thin-shell structures. But it did not gain much popularity because there are several disadvantages inherent in the conventional finite difference method: problems with convergence 
of numerical results, pick stresses, intersecting line of connecting shells and difficulty in approximating differences of rigidities of such shell structures, difficulty in incorporation of the boundary conditions at types of boundaries, and limitations of generating fine meshes complicated features of such shell structures should be faced by structural engineers and who must tackle to get results in accuracy for proper design. In this paper a non-traditional and very new procedure for the elastic analysis of thin-walled structures is presented. This procedure is based on a new numerical method - solution of various existing unknown forces and stresses, which is similar to the finite difference method, but in simple way to understand their features by students. Moreover, such types of structures can be used to resist earthquake forces which is more important for our country Nepal.

The linear theory of thin elastic shells with arbitrary shape of the middle surface is derived on the basis of Kirchhoff's assumptions that were used in the development of the plate bending theory introduced in Part I. These assumptions are formulated for the linear theory of thin shells of an arbitrary shape, as follows:

1. Normal to the undeformed middle surface remain straight and normal to the deformed middle surface and undergo no extension. This assumption implies that all the strain components (normal and shear) in the direction of the normal to the middle surface vanish.

2. The transverse normal stress is small compared with other normal stress components and may be neglected. Novozhilov showed that the error introduced by the Kirchhoff hypotheses in the theory of thin shells is of the order $h / R$ in comparison with unity, in which $h$ and $R$ are the shell thickness and radius of curvature of the middle surface, respectively. It is assumed that the thickness of the shell is small compared with other dimensions, for example, the smallest radius of the middle surface of the shell (see the inequality. We also assume that the displacements of an arbitrary point of a shell are small in comparison to its thickness. As a consequence of this assumption, the products of the displacements and their partial derivatives will be neglected as second-order quantities of smallness. Furthermore, we can refer all calculations to the original configuration of the shell and ensure the differential equations will be linear. From here on we assume that the material of the shells is homogeneous, isotropic and that it obeys Hooke's Law.

Envelopes of thin shell designs is used in differrent areas of mechanical engineering, shipbuilding, construction, the aviation and space industry. In this report work linear theory of envelopes based on hypotheses Kirchhoff - Love is used. Thus, restriction by frameworks of the technical theory can be proved the general complexity of a problem and enough greater class of designs for which hypotheses of the classical theory of envelopes are corrected

Apparently, from a brief review at analysis or calculation of thin shells of complex geometry, the variation difference method and the finite element method are the used numerical methods. It is connected with complexity of the initial equations of the theory of shells of complex geometry. By consideration of new types of shells, it is necessary to study, first of all, the geometry of the middle surface to receive necessary geometrical characteristics: coefficients of square-law forms, the main radiuses of curvature necessary for preparation of the basic equations of shells. It speaks that in the special literature, the devoted geometry of the certain types of surfaces, in the majority of cases analytical expressions of these characteristics are not considered. In this report, shells in the form of carved surfaces of Monge are considered $[2-4 ; 15 ; 16 ; 18]$. It is studied surfaces of Monge (figure 1) [15] and their geometry is stated, formulas of factors of square-law forms. The algorithm variation-differential method [4; $9 ; 19-21]$ is developed and realized on the structural analysis program too.

\section{Description and solution at intersecting line of shells; creation of complexity}

The problem of the study of this report is to identify simple way of solution to analyze complicated features of thin shell structure by introducing modern and new programmable theories and aspects. Especially the intersecting line of connecting thin shell structures and having different rigidities has to be identified and enormous nodes selecting along those intersecting lines to be analyzed with various simple methods like force and displacement or matrix methods which is known by students and using those they can analyze even more complex structures in geometry and types of loadings.

Nepalese skilled manpower who wants construct structure in healthy, complex in geometry and economic sense will be involved in field survey, lab work. Appropriately qualified and well motivated students for field exposure are identified, will be given orientation and employed for research work in this research topic. 


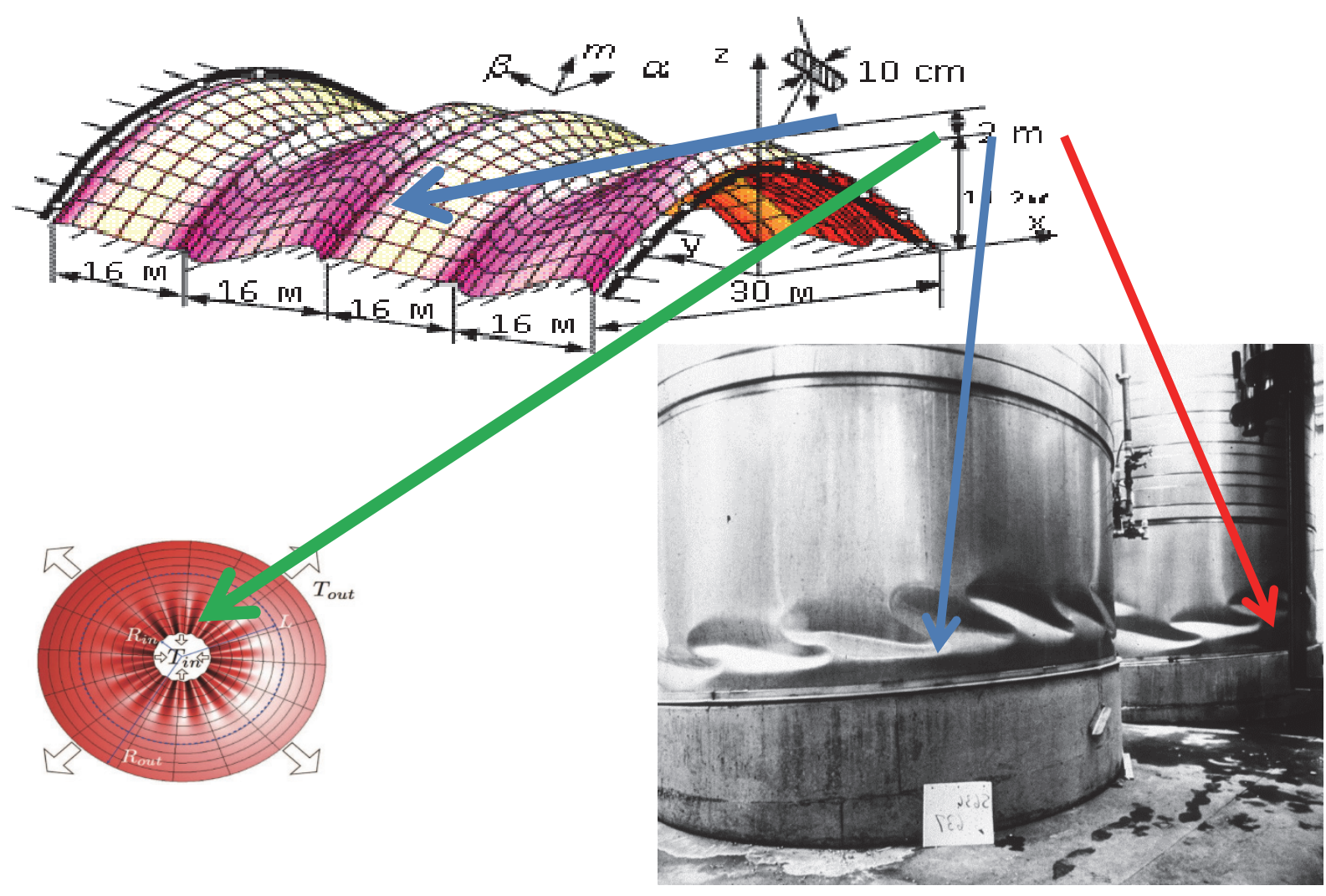

Figure 1. Thin shell with complexity in intersecting line

\section{Results and Discussion}

The conclusions based on this paper are as follows. It is possible to successfully model explicitly a panel profile that can be used for optimization studies for use as possible future test studies. It has also been shown, that if test data exists, a numerical solution can be very accurately modeled to match the test data by modifying the material properties of the model. This modification will take into account any stiffening effects, as well as the influence of geometric parameters that cannot be readily accounted for, such as panel corrugation. In addition, upon verification of a modified material stiffness curve which accurately matches recorded test data, the stiffness curves can be used to model full scale buildings by applying the characteristics of the stiffness curves to various portions of the full scale model. The claims made by other researchers stating that a linear elastic solution cannot be used to solve problems involving thin shell arch panels has been confirmed by the research in this paper. Rather, a nonlinear solution (figure 3 ) is the most precise method for obtaining accurate solu- tions to the panel in question. For future tests, it is suggested to evaluate multiple material thickness panels to establish any existing relationship between material thickness and panel radius concerning with finite element method. It is surmised and theorized that the trend of ultimate failure load decreasing as radius is decreased will hold true for various material thickness. The theory stating that the loads will be lower if the material thickness is decreased, and the loads going higher if the material thickness is increased.

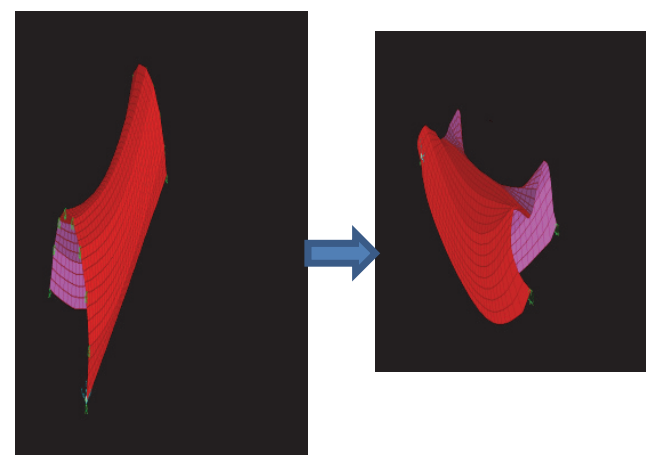

Figure 2. Complexity after deformation of shell structure 

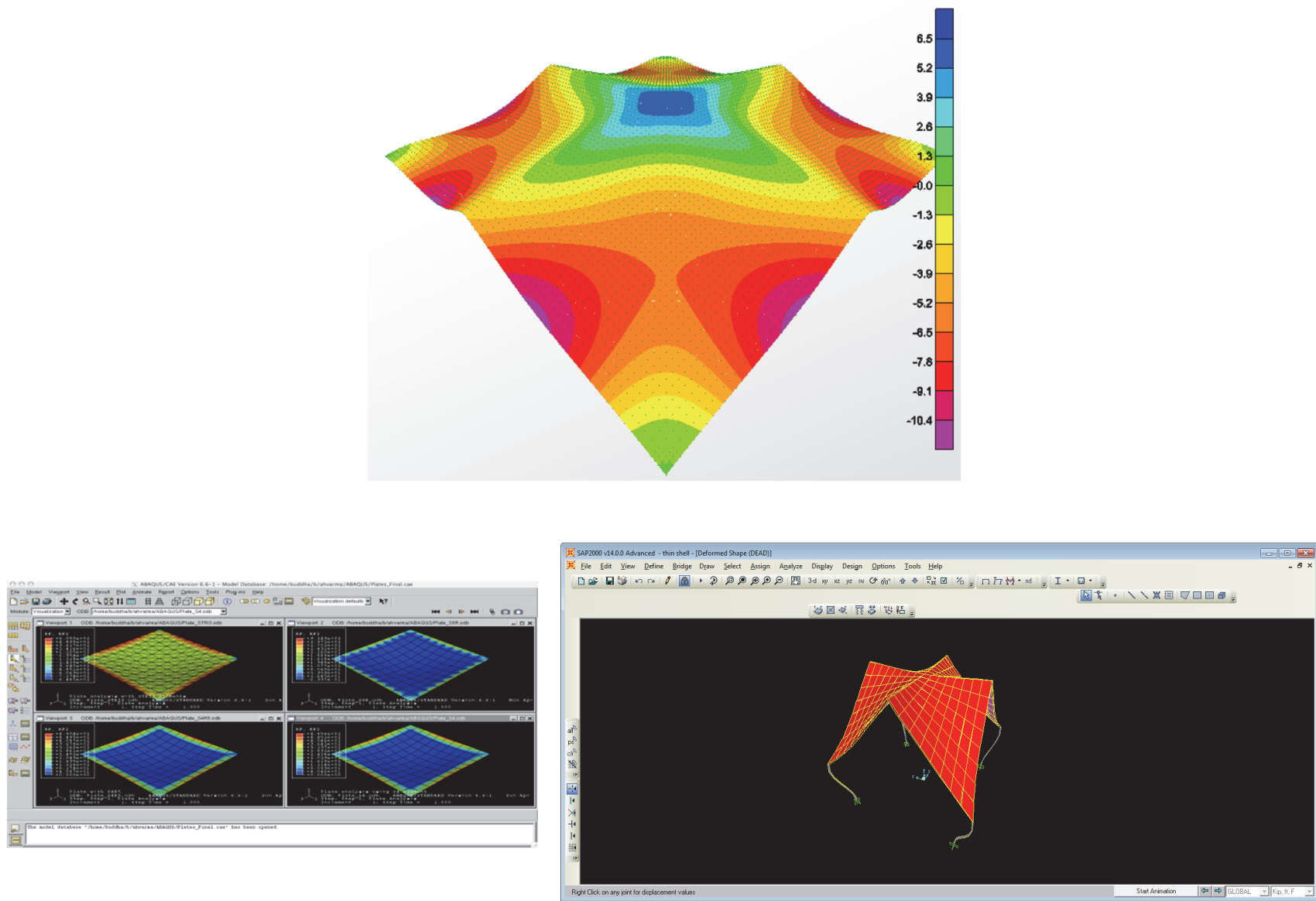

Figure 3. Deflection contour created in SAP2000

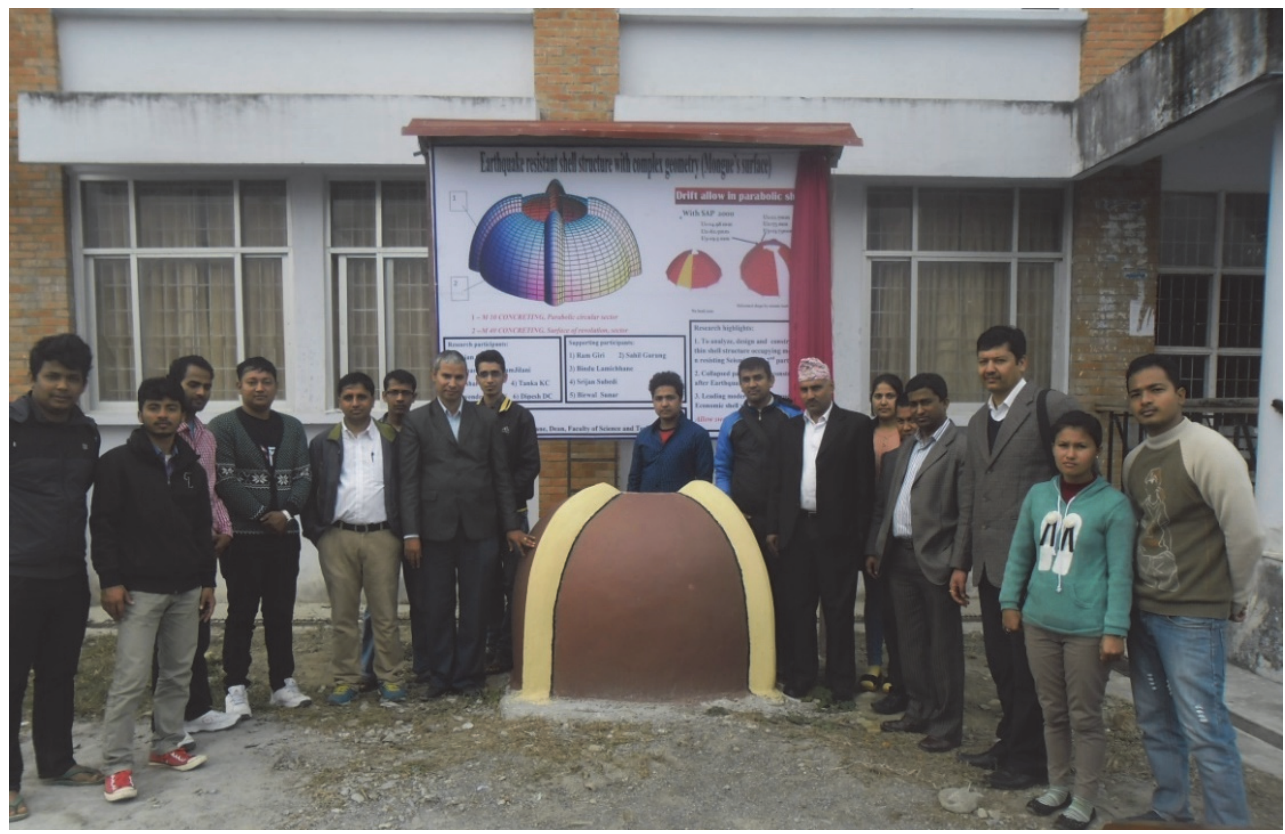

Figure 4. Shell model created near School of Engineering, Pokhara University 


\section{Other Results}

1. Examples of thin-walled designs from crossed sectors of shells are lead.

2. Conditions of the teamwork, crossed sectors of shells are received.

3. The algorithm of calculation of crossed sectors of shells is developed by a method of global elements.

4. The module of a program complex of calculation thin-walled spatial designs variation-differential method by a method, realizing calculation of crossed sectors of shells is developed.

5. Calculations of crossed sectors of shells with application variation-differential method and a method of global elements on various kinds of loadings are lead.

6. Are constructed graphics internal efforts and pressure, the analysis of the is intense-deformed condition of crossed sectors of shells on the basis of the received numerical results is lead and created model (figure 4).

\section{Conclusion}

The research paper is devoted to the specific research for analyses of crossing sectors of shells or plates, design and construction and also development and realization on the calculation of a method of global elements of crossed sectors of shells with complex geometry.

The various examples of crossing sectors of shells are briefly shown in dissertations and are considered various constructive forms, for example crossing plate designs, plate-shell crossing designs and shell to shell crossing designs.

For calculation of crossing sectors of shells of complex geometry the program of the variation difference method and global element method is used. The module of the program complex realizing calculation of crossed sectors of shells will be developed. The given algorithm is universal enough and allows calculating various designs on uniform algorithm. Under the realized program test calculations of traditional designs which were compared to known decisions are lead. Calculations have shown good concurrence of results. Calculation of a thin-walled design of shells is executed. Calculations are lead on action of a self-weight and wind load. The received numerical results have no analogues will be in the literature. Finally it will be worth evaluation for Pokhara and Mid-Western University leading support to development of country in modernization in structural engineering.

\section{Recommendations}

The report should encourage structural engineers to solve complicated features in thin shell structures and design for construction of such structure which are rarely constructing in country like Nepal due to lack of skilled manpower.

(C) Govind Prasad Lamichhane, 2018

This work is licensed under a Creative Commons Attribution 4.0 International License

\section{References}

1. Chernykh K.F. (1964). Linear Theory of Shells. Part 2. Leningrad State University Press. (In Russ.)

2. Krivoshapko S.N., Ivanov V.N. (2015). Encyclopedia of Analytical Surfaces. Switzerland, Springer International Publishing, 752.

3. Ivanov V.N., Romanova V.A. (2016). Constructional forms of the space constructions. Visualization of the surfaces at the systems MathCad, and AUTOCad. Moscow, ASV Publ., 412.

4. Ivanov V.N., Krivoshapko S.N. (2010). Analytical methods of analyses of the shells of noncanonic forms. Moscow, RUDN Publ., 542.

5. Graves Smith T.R., Gierlinski I.T., Walker B. (1995). A combined finite strip. Finite element method for analyzing thin walled structures. Thin Walled Struct., (3), 163-180.

6. Cowper G.R., Lindberg G.M., Olson M.D. (1970). A shallow shell finite element of triangular shape. Int. J. Solids Struct., (6), 1133-1156.

7. Clough R.W., Johnson R.L. (1968). A finite element approximation for the analyses of thin shells. Int. $J$. Solids Struct., (4), 43-60.

8. Strickland G.E., Loden W.A. (1968). A doublycurved triangular shell element. Proceedings of the $2^{\text {nd }} \mathrm{Con}$ ference on Matrix Methods in Structural Mechanics. Ohio, Wright-Patterson AFB.

9. Ivanov V.N. (2008). The base of the finite element method and the variation-difference method. Moscow: RUDN Publ., 168.

10. Furnike T. (1972). Computerized multiple level substructuring analysis. J. Comput. Struct., (2), 1063-1073.

11. Noor A.K., Kamel H.A., Fulton R.E. (1978). Substructuring techniques status and projections. J. Comput. Struct., 8(5), 621-632.

12. Totoev Y.Z. (1988). Stress-strain state of the combined plate \& shell type structures. Ph.D. Thesis. Kiev State Technical University of Construction and Architecture. (In Russ.)

13. Totoev Y.Z., Gotsulyak E.A. (1995). The use of the curvilinear mesh method in a super-element procedure for analysis of complex thin-walled structures. Proceedings of the 14 Australian Conference on the Mechanics of Structures and Materials, Hobart, Tasmania, (1), 124-129. 
14. Govind L. (2004). At analyses of the section of the shell of complex geometry. Materials of the All-Russian exhibition of the technical-science creation of the youth (NTTM-2004), Moscow, VVC, 7-10 April 2004, 14-15.

15. Ivanov V.N., Govind L. (2005). Connection of coordinates on surfaces and global coordinates system for Monge's surfaces. Structural Mechanics of Engineering Constructions and Buildings, (1), 43-48. (In Russ.)

16. Govind L. (2007). Analyses of intense-deformed condition of crossing sections of shells by methods of global elements. Diss. of Ph. Doc. of Technical Sciences. Moscow, RUDN Publ., 143.

17. Ivanov V.N. (2008). The problems of analyses of combined thin space constructions. Engineering Systems 2008, Russian Science-Practical Conference. Moscow, 7-8 April. Moscow, RUDN Publ., 195-201.

18. Ivanov V.N., Rizvan Muhammad. (2002). Geometry of Monge surfaces and construction of the shells. Structural Mechanics of Engineering Constructions and Buildings. Interuniversity Collection of Science Works, (11), 27-36. Moscow, ASV Publ.

19. Ivanov V.N. (1982). Variation-difference method of analyses of plates and shells. Analyses and design of building constructions. Moscow, UDN Publ., 131-141.

20. Ivanov V.N., Nasr Yunes Abbushy. (2000). Analyses of the shells of complex geometry by variation- difference method. Structural Mechanics of Engineering Constructions and Buildings. Interuniversity Collection of Science Works, (9), 25-34. Moscow, ASV Publ.

21. Ivanov V.N., Kushnarenko I.V. (2013). The Variational-Difference Method for the Analysis of the Shells with Complex Geometry. International Association for Shell and Spatial Structures. Proceedings of the IASS 2013 Symposium "Beyond the Limits of Man", Wraclaw, Poland, 23-27 September 2013. Full Papers. Paper ID 1410. Wroclaw, Oficyna Wydawnica Politechniki Wroclawskiej, 6.

\section{About the author}

Govind Prasad Lamichhane - $\mathrm{PhD}$ in Technical Sciences, Associate Professor, Pokhara University, Dean in Mid-Western University (Birendranagar, Nepal). Research interests: thin shells structures. Contacts: e-mail govindkhec@gmail.com

\section{For citation}

Govind Prasad Lamichhane. (2018). Complicated features and their solution in analysis of thin shell and plate structures. Structural Mechanics of Engineering Constructions and Buildings, 14(6), 509-515. DOI: 10.22363/18155235-2018-14-6-509-515

НАУЧНАЯ СТАТЬЯ

\title{
Конструктивные особенности и их решение при расчете тонких оболочек и пластин
}

\author{
Говинд Прассад Ламичхане
}

\author{
Mid-Western University \\ Post Box 21700, Kuhine Pani, Birendranagar, Surkhet, Nepal
}

(поступила в редакцию: 02 августа 2018 г.; доработана: 08 октября 2018 г; принята к публикаиии: 10 ноября 2018 г.)

Поучительно с исторической точки зрения рассмотреть, каким образом внедрение тонкой оболочки как конструктивной формы внесло важный вклад в развитие нескольких отраслей машиностроения. В статье дан краткий обзор, не претендующий на всеобъемность, решений для расчета таких конструкций.

Тонкая оболочка - это трехмерная пространственная конструкция, состоящая из одной или нескольких изогнутых плит или сложенных пластин, толщина которых мала по сравнению с другими их размерами. Тонкие оболочки характеризуются трехмерным несущим поведением, которое определяется геометрией их форм. Тонкие пластины изначально представляют собой плоские конструкции, ограниченные двумя параллельными плоскостями, называемыми гранями, и цилиндрической поверхностью, называемой ребром (или границей). Образующие цилиндрической поверхности перпендикулярны плоским граням. Геометрически пластины ограничены либо прямыми, либо изогнутыми границами. Статические или динамические нагрузки, переносимые пластинами, преимущественно перпендикулярны их поверхностям. Несущее действие пластины в некоторой степени аналогично действию балок или кабелей; таким образом, в зависимости от изгибной жесткости конструкций пластины могут быть аппроксимированы сеткой из бесконечного числа балок или сетью из бесконечного количества кабелей. В результате двумерного конструктивного действия пластин конструкции получаются более легкими, что дает многочисленные экономические преимущества. Пластина, будучи изначально плоской, развивает поперечные силы, изгибающие и крутящие моменты, чтобы противостоять поперечным нагрузкам. При расчетах инженер-строитель должен учитывать, 
что тонкие оболочки, связанные друг с другом, могут иметь различную жесткость. Численные решения подобных сложных задач осуществляются с помощью систем автоматизированного проектирования, например SAP2000 (САП2000), Staad Pro (Стаад Про) и т.д.

Ключевые слова: пространственная конструкция, тонкие оболочки, поверхности, поверхности Монжа, методы расчета

\section{Список литературы}

1. Черных К.Ф. Линейная теория оболочек: в 2 ч. Ч. 2. Л.: Изд-во Ленингр. ун-та, 1964. 395 с.

2. Krivoshapko S.N., Ivanov V.N. Encyclopedia of Analytical Surfaces. Switzerland: Springer International Publishing, 2015. $752 \mathrm{p}$.

3. Иванов В.Н., Романова В.А. Конструкционные формы пространственных конструкций. Визуализация поверхностей в системах MathCad и AUTOCad: монография. М.: АСВ, 2016. 412 с.

4. Иванов В.Н., Кривошапко С.Н. Аналитические методы расчета оболочек неканонической формы: монография. М.: РУДН, 2010. 542 с.

5. Graves Smith T.R., Gierlinski I.T., Walker B. A combined finite strip. Finite element method for analysing thin walled structures // Thin Walled Struct. 1995. No. 3. Pp. 163-180.

6. Cowper G.R., Lindberg G.M., Olson M.D. A shallow shell finite element of triangular shape // Int. J. Solids Struct. 1970. No. 6. Pp. 1133-1156.

7. Clough R.W., Johnson R.L. A finite element approximation for the analyses of thin shells // Int. J. Solids Struct. 1968. No. 4. Pp. 43-60.

8. Strickland G.E., Loden W.A. A doubly-curved triangular shell element // Proceedings of the 2nd Conference on Matrix Methods in Structural Mechanics, WrightPatterson AFB, Ohio, 1968.

9. Иванов В.Н. Основы метода конечных элементов и вариационно-разностного метода: учебное пособие. М.: Изд-во РУДН, 2008. 168 с.

10. Furnike T. Computerized multiple level substructuring analysis // J. Comput. Struct. 1972. No. 2. Pp. 1063-1073.

11. Noor A.K., Kamel H.A., Fulton R.E. Substructuring techniques status and projections // J. Comput. Struct. 1978. Vol. 8. No. 5. Pp. 621-632.

12. Тотоев Ю.З. Напряженно-деформированное состояние комбинированных пластинчато-оболоченных конструкций: дис. ... канд. техн. наук. Киев, 1988. 155 с.

13. Totoev Y.Z., Gotsulyak E.A. The use of the curvilinear mesh method in a super-element procedure for analysis of complex thin-walled structures // Proceedings of the 14 Australian Conference on the Mechanics of Structures and Materials, Hobart, Tasmania. 1995. Vol. 1. Pp. 124-129.

14. Говинд Л. К расчету сопряжений отсеков оболочек сложной геометрии // Сборник материалов Всероссийской выставки научно-технического творчества молодежи (НТТМ-2004), Москва, ВВЦ, 7-10 апреля 2004 г. C. $14-15$.
15. Иванов В.Н., Говинд Л. Связь поверхностной и глобальной систем координат для резных поверхностей Монжа // Строительная механика инженерных конструкций и сооружений. 2005. № 1. С. 43-48.

16. Говинд Л. Исследование напряженно-деформированного состояния пересекающихся отсеков тонких оболочек методом глобальных элементов: дис. ... канд. техн. наук. М.: Изд-во РУДН, 2007. 143 с.

17. Иванов В.Н. Проблемы расчета комбинированных тонкостенных пространственных конструкций // Сборник трудов Всероссийской научно-практической конференции «Инженерные системы - 2008», Москва, 7-10 апреля 2008 г. М.: Изд-во РУДН, 2008. С. 195-201.

18. Иванов В.Н., Ризван М. Геометрия резных поверхностей Монжа и конструирование оболочек // Строительная механика инженерных конструкций и сооружений: межвузовский сборник научных трудов. Вып. 11. М.: АCВ, 2002. С. 27-36.

19. Иванов В.Н. Вариационно-разностный метод расчета пластин и оболочек // Расчет и проектирование строительных конструкций. М.: УДН, 1982. С. 131-141.

20. Иванов В.Н., Наср Ю.А. Исследование сходимости при расчете пластин вариационно-разностным методом. Проблемы теории и практики инженерных исследований. М.: АСВ, 2000. С. 53-56.

21. Ivanov V.N., Kushnarenko I.V. The VariationalDifference Method for the Analysis of the Shells with Complex Geometry // International Association for Shell and Spatial Structures Proceedings of the IASS 2013 Symposium "Beyond the Limits of Man", Wraclaw, Poland, 23-27 September 2013. Full Papers. Paper ID 1410. Oficyna Wydawnica Politechniki Wroclawskiej, Wroclaw, 2013. 6 p.

\section{Oб авторе}

Говинд Прассад Ламичхане - кандидат технических наук, декан Mid-Western University (Бирендранагар, Непал). Область научных интересов: тонкие оболочки, большепролетные покрытия. Контактная информачия: e-mail -govindkhec@gmail.com

\section{Для цитирования}

Говинд Прассад Ламичхане. Конструктивные особенности и их решение при расчете тонких оболочек и пластин // Строительная механика инженерных конструкций и сооружений. 2018. Т. 14. № 6. С. 509-515. DOI: 10.22363/1815-5235-2018-14-6-509-515 